\title{
The Holy Spirit and the Early Church: Doctrine \& Confession
}

\begin{abstract}
Author:
Johannes van Oort ${ }^{1,2,3}$

Affiliations:

${ }^{1}$ Department of Ecclesiastical History, University of Utrecht,

The Netherlands

${ }^{2}$ Department of Ecclesiastical History, Radboud University,

The Netherlands

${ }^{3}$ Department of Church History and Church Polity, University of Pretoria, South Africa

Note:

Prof. Dr Johannes van Oort is Professor Extraordinarius in the Department of Church History and Church Polity of the Faculty of Theology at the University of Pretoria, South Africa.

Correspondence to:

Hans van Oort

Email:

j.van.oort@planet.nl

Postal address:

Van Renesselaan 24, $3703 \mathrm{AH}$

ZEIST, The Netherlands

Dates:

Received: 24 June 2011

Accepted: 28 July 2011

Published: 04 Nov. 2011

How to cite this article: Van Oort, J., 2011, 'The Holy Spirit and the Early Church: Doctrine \& Confession', HTS Teologiese Studies/ Theological Studies 67(3), Art. \#1120, 8 pages. http:// dx.doi.org/10.4102/hts. v67i3.1120
\end{abstract}

This article firstly investigates in what way various main theological figures in the first centuries of the Christian era spoke about the Trinity and thus, also, about the Holy Spirit. Secondly, it investigates how the formulas of Early Christian confessions of faith developed into their mature and final forms. Such (baptismal) confessions often reveal trinitarian expressions and explicit wordings about the Holy Spirit.

\section{Introduction}

Our subject has a complex character. Indeed, one cannot speak about an Early Christian doctrine of the Holy Spirit without mentioning the various and developing doctrines of the Trinity. One of the key lines of inquiry will be: in what way did various people in the first centuries of the Christian era speak about the Trinity and thus, also, about the Holy Spirit? We will consider only the main theological figures from both the Eastern and Western traditions.

In addition, there is a second (and perhaps more important) line of thought. We will investigate how the formulas of early Christian confessions of faith developed into their mature and final forms, particularly those confessions spoken at baptisms or the catechetical instructions that preceded baptisms. Such confessions often reveal trinitarian expressions and explicit wordings about the Holy Spirit. From the baptismal faith confession emerged the fixed symbol.

Thirdly, and in a separate HTS Theologiese Studies/Theological Studies article, we would like to pursue still another line of thought. There we will focus on the gifts of the Spirit, that is, how the Holy Spirit was experienced in both the individual and the community lives of the early church. The latter may end up being the most intriguing investigation related to our topic. Currently relevant questions and debates regarding the gifts of the Spirit, the charismata of prophecy, speaking in tongues and spiritual healing, amongst other things, would undoubtedly be enriched by the results of historical research.

Thus, there are three lines of enquiry from which to approach the topic. It should be stressed that all three lines are interrelated. The eventual dogmatic formulation of the early church is not the result of pure theological reasoning or even philosophical (mainly Neo-Platonic) speculation, but is closely related to the practice of early Christian baptism, particularly its liturgy, the catechetical instructions that preceded it and, not least of all, the early Christians' experience of the Holy Spirit during baptism.

Abbreviations of original source editions will be used in order to save space: CCL = Corpus Christianorum, Series Latina; GCS = Die griechischen christlichen Schriftsteller der ersten drei Jahrhunderte; MPG = J.-P. Migne, Patrologiae cursus completus, Series Graeca; SC = Sources Chrétiennes.

\section{The doctrine of the Holy Spirit}

\section{The Spirit as a gift from God and a mode of God's being}

In the development of trinitarian doctrine during the first centuries, we discern, with regard to the Holy Spirit, two main concepts alongside and sometimes opposing one another (Lebreton 1927-1928; Schmidt 1958; Kettler 1962; Veenhof 1974; Crouzel 1976; Ritter 2000; Oberdorfer 2005; Raddle-Gallwitz 2011). The Spirit is seen, on the one hand, as a gift from God and on the other, as a mode of God's being. Albeit closely together, the occurrence of both these understandings of the Spirit remains a feature of later orthodox doctrine. In this regard, reference may be made to Augustine. When, in his Enchiridion or 'Handbook on Faith, Hope and Charity', he speaks of the unity of the son of God and the son of man in Jesus Christ, his point of reference is the Holy Spirit: 'This grace was to be signified by the Holy Spirit, because He is Himself so truly God that He may 
also be called the gift of God'. ${ }^{1}$ Both in the East and West we come across this view.

\section{Irenaeus, theologian of the Holy Spirit}

In a number of early Christian writings we find important elements of a doctrine of the Holy Spirit. A remarkable amount of material is provided by Irenaeus, bishop of Lyon around 180-185, in his work "Against Heresies" (Adversus Haereses ). Irenaeus was a theologian of the Holy Spirit par excellence (Jaschke 1976; cf. Minns 2010). Trinitarian formulas frequently appear in his work. In this context, Irenaeus sees the Spirit as a 'person', just like the Father and the Son. More than once he refers to Christ and the Spirit as 'the two hands of God' (e.g. sections 5, 28,4). ${ }^{2}$ Time and again he speaks of the Spirit's work in creating the world $(5,1,1$.), with reference to the Scriptures (Jaschke 1976:249-265), Christ (Jaschke 1976:233-249, 282-288), the Church (Jaschke 1976:208-233), and the individual Christian (Jaschke 1976:265-327). The Son and the Holy Spirit partook in creating the world; they were the two hands of the Father (Adversus Haereses 4, Pref. 4). ${ }^{3}$ The Spirit and the Son are the sources of inspiration of Scripture and prophesy (Adversus Haereses passim). The Holy Spirit is the finger of God, ${ }^{4}$ which wrote the Decalogue on the stone tablets (Irenaeus, Demonstratio 26; cf. Mambrino 1957:358). The Spirit descended upon Jesus at his baptism and sanctified his humanity (Adversus Haereses 3, 9, 3). The Spirit continues Christ's work in the church, which is itself a gift from the Spirit (Jaschke 1976:266-267). The expression 'Where the Church is, there is also the Spirit of God; where the Spirit of God is, there is also the Church and all grace' (Adversus Haereses 3, 24, 1; SC 211, 474) has become crucially important in subsequent Christian tradition. Finally, and equally significant, the Holy Spirit is the Spirit of the sanctification of man and his transformation into the image of Christ, living in us to grant divine life to us. This very same Spirit is also the source of all charismata.

We shall return to the latter, for Irenaeus speaks extensively and in a surprising manner about the charismata. Also, we shall return to the links Irenaeus's doctrine of the Holy Spirit shares with the baptismal confession and the so-called 'rule of faith' (regula fidei). As indicated earlier in this article, the Gallic bishop Irenaeus had a comprehensive doctrine of the Holy Spirit, the most complete one found amongst the earliest Christian theologians. Essential elements of this doctrine resurface in later Christian writers such as Tertullian. This first North African theologian was very familiar with Irenaeus's ideas.

1.Enchiridion 12, 40 (CCL 46, 72): 'Quae gratia propterea per spiritum sanctum fuera significanda, quia ipse proprie sic est deus, ut dicatur etiam dei donum.' See also $D e$ trinitate 5,$12 ; 5,15 ; 15,17$. In the latter chapter, he also writes in detail about God the Holy Spirit being love: 'Ipse (sc. spiritus sanctus) ergo significatur ubi legitur: Deus dilectio est. Deus igitur spiritus sanctus qui procedit ex deo cum datus fuerit homini accendit eum in dilectionem dei et proximi, et ipse dilectio est' etcetera (CCL 50A, 506).

2.Philo (in De plantatione 50) already spoke about the 'hands' of God as his creative powers (cf. Adam 1970:160).

3.The metaphor is intended to express that the Spirit is the instrument by which God imparts sanctification to his creation. According to Lebreton (1928:576-589) and Mambrino (1957:355-370), this is not subordination.

4.Gross (1969:944-945). Compare this with Matthew 12:28, Luke 11:20 and, in the famous hymn Veni Creator Spiritus, the expression: 'You are the Finger of God's righ hand' (dextrae Dei tu digitus)

\section{Tertullian}

The very influential Tertullian (c. 160/170-† after 220) speaks rather reservedly about the Holy Spirit. The centre of his theology is Christ (Bender 1961:91, 98). This does not mean that he did not think and speak in a theoretical way about the Holy Spirit. On the one hand, the Spirit is considered to be the vicarious power (vicaria vis) of the Son. The Spirit is bestowed as a gift from the Father, through the Son (a patre per filium $)^{5}$, onto the Church. On the other hand, Tertullian speaks about the 'person' of the Spirit, who works within and watches over the Church. The Church, in turn, speaks to us through scripture, which is the book of the Holy Spirit (Bender 1961:115-123). This Spirit is given to us at baptism, the very same Spirit who raised Christ from the dead and will also raise our deceased bodies (e.g. Bender, passim).

In his (often polemical) writings, however, Tertullian's main emphasis is on the doctrine of the Trinity. He speaks extensively about the Trinity in his work against a certain Praxeas and also anticipates the classical formula of tres personae, una substantia (e.g. Adverus Praxean 13; CCL 2, 1173-76). In attempting to describe the Trinitarian mystery, Tertullian speaks not only of the autonomy of each of the different 'persons', but also of them being 'of one substance' (Kelly 1968:114-115). His ideas possibly tend to subordinate the Spirit to the other 'persons' of the Trinity, which leads one to question the extent to which the proclaimed unius substantiae of one substance') of the Spirit has an essential and eternal character (De Boer 1963-1964:364). ${ }^{6}$ We shall return to Tertullian's links with Montanism, revealing another, perhaps even more interesting, side to this charismatic Christian from Africa.

\section{Novatian and Hilary}

Novatian († c. 258) and Hilary (c. 315-367) were both from what is traditionally referred to as the 'West'. Novatian, the first theologian in Rome who wrote in Latin, is seen as having followed in the footsteps of Tertullian. His Stoicallyinfluenced way of thinking compelled him to describe the divine Trinity, like Tertullian at times, in terms of subordination. In his De Trinitate (CCL 4, 11-78), he only writes briefly about the Spirit. He emphasises the Spirit's 'personhood', but also speaks of the Spirit as a divine gift (donum), the source of all godly life.

Hilary of Poitiers stresses the unity of the Trinity in his De Trinitate (CCL 62-62A), but also calls the Spirit a gift (donum fidelium). The twelve books of his most prominent work focus on Christology and are directed against the Arians.

5.Adversus Praxean 4 (Corpus Christianorum 2, 1162). This formula best expresses Tertullian's view. But later on we read in Adv. Prax. 8 (Corpus Christianorum 2, 1168): 'Tertius enim est Spiritus a Deo et Filio.' This makes it clear that the socalled Filioque has very old roots in the theology of the Western Church (cf. Loofs 1968:123, n. 4).

6.Loofs (1968:120-121) states that, for a relatively extended period, Tertullian, possibly by Roman influences, thought in a binitarian-monotheistic way. Nonetheless, this line of thinking was later overcome by the so-called Asia-Minor theology, which was especially strong in his Montanistic period. Bender (1961:150-171), however, states especially strong in his Montanistic period. Bender (1961:150-171), however, states
that Tertullian remained true to his essential opinions and that he spoke of the Holy Spirit as a 'person' from the beginning. 
From the aforementioned argument it should be evident that others in the Latin West tried to steer a middle course between subordination and modalism. In this context, 'subordination' means that the Holy Spirit was regarded as being subordinate (and thus inferior) to both the Father and the Son. With 'modalism' is meant the plethora of teachings that emphasised the oneness of God, thereby denying the permanence of the three 'Persons' by maintaining that the distinctions in the Godhead were only transitory modes of being. These opinions were all later considered to be unorthodox. From early on, Western theologians stressed the 'substantial' unity of the three 'persons'. Tertullian gave expression to this conviction: tres personae, una substantia. Accordingly, the Holy Spirit was considered to be a 'Person' as well.

We now turn to the developments of early Christian doctrine in the Eastern regions of the world. As with our discussion on scholars from the western regions, space only allows us to describe some key developments. Our attention focuses on Origen, Athanasius and Basilius.

\section{Origen and Arius}

Origen (c. 185/6-c. 253/4) is a pivotal figure, without whom the theology developed in the Greek East would be unthinkable, even though he was later condemned at important councils of the Church. Origen, born and educated in Egyptian Alexandria, as well as his influential theological school, always considered the Spirit to be a 'Person'. The German theologian, Georg Kretschmar (1956:71-78) pointed out that Origen's theology was influenced by archaic JewishChristian concepts, as can be seen, for example, in the Ascension of Isaiah (cf. Quispel 1964/2008). ${ }^{7}$ In particular, however, Origen was influenced by Neo-Platonic ideas. Although he taught an eternal generation of the Son, he saw the Spirit as a divine hypostasis (lit. 'substance', but in ecclesiastical parlance meaning 'being', 'individual reality', even 'person') subordinate to the Son. As such, the Spirit's status is inferior and subordinate to that of the Logos. Resultantly, the Spirit's sphere of influence is also lesser than that of the Son.

Arius († 336), presbyter of the Baucalis church at Alexandria, later drew excessive conclusions from Origen's theology. Arius did indeed call the Logos 'Theos', but he meant: god of a sort. He did not use the article and speak of Ho Theos. Thus,

7.Kretschmar (1956:78ff.) also elaborates on the vision of the seraphim of Isaiah $6: 1 \mathrm{ff}$., as interpreted by Origen and others. Before Origen, Jesus Christ and the Holy Spirit were considered to be the two seraphim of Isaiah 6 . It is important to note (with Lebreton 2, XIV-XXI) that, by referring to these two angels, early Christian theologians wanted to stress the originally 'personal' character of both Christ and the Spirit, not that they were 'creatures' of the Father. Kretschmar saw in the image of these two highest angels or 'paracletes' the oldest form of trinitarian doctrine and described it as typical of Jewish Christianity. I would also (even more than Kretschmar 82ff.) like to point to the influence the Jewish theologian Philo had upon the more Hellenistic forms of early Christianity (cf. Barbel 1958:49-58; Daniélou 1957:5-41, 1958:167-198, 413-418). The early Christian concept described as both 'angel christology' and 'angel pneumatology' is not as strange as might initially be angel christology and angel pneumatology is not as strange as might initially be thought. Attention could be drawn to the early Christian exposition of Genesis 18 in the wake of Philo; the Jewish and early Christian concept of the Angel of the Lord (cf. Barbel 1961; Fossum 1985). Later on, the Arians considered Christ to be an angel. In reaction, the concept mostly disappeared in the works of orthodox writer (cf. Zandee 1981:498-584, esp. 517ff., 522-556 \& 570ff). See, moreover, on various forms of 'angelomorphic' pneumatology, for example, Bucur (2007); Bucur (2009); Briggman (2009) and Briggman (2010).
Arius became a champion of a 'subordinationist' teaching about Christ. Although he also dealt with the notion of trias (tripartite), Arius did not acknowledge a divine trinitas as such. He explicitly spoke of three 'persons' (hypostaseis), but he did not consider them to be of the same status. As a consequence of his whole view, but contrary to (later) 'orthodox' teaching, Arius did not speak of any divinity of the Holy Spirit.

\section{Athanasius: Theopoièsis and the divinity of the Holy Spirit}

Athanasius of Alexandria (c. 296-373) provides us with an immense amount of material about the emergence of the doctrine of the Holy Spirit. The theology of the famed 'father of orthodoxy', first deacon and later bishop of the church of Alexandria, has two focal points. Firstly, he emphasised the essential affiliation of the Son with the Father. Secondly, he stressed in no small way 'deification' as the purpose of men's salvation. The term 'deification' does not imply the pagan idea whereby a human is changed into a divine being, but rather denotes that the Christian believer has complete entry into the sphere of Christ. According to Athanasius, the purpose of deification, or theopoièsis, ${ }^{8}$ is the full unification of the Christian with his Lord, Jesus Christ. The Holy Spirit brings about this union.

In his work, On the Incarnation of the Word, Athanasius wrote extensively about the divinity of the Son. Later, he also wrote a number of letters to a certain Serapion about the divinity of the Spirit. ${ }^{9}$ One citation from these letters might illustrate his belief about the Spirit: 'If He deifies, it is beyond doubt that His nature is that of God' (Ep. ad Serapionem 1, 24; SC 15, 126 \& MPG 26, 588: ei de theopoiei, ouk amphibolon hoti hè toutou physis theou estin). Even though he doesn't explicitly say so, Athanasius thought of the Spirit as God. His use of the famous term homoousios ${ }^{10}$ in relation to the Holy Spirit is particularly revealing in this regard. Finally, it is important to note that Athanasius did not consider the work of the Spirit to be limited to believers only. On the contrary, the Spirit is at work everywhere in God's creation (Roldanus 1968/1977:232; Shapland 1951:184, n. 7).

\section{The Cappadocian fathers}

Whereas Athanasius strongly emphasised God's unity, the so-called Neo-Nicene party took up the task of further formulating the concept of the Trinity. They spoke of three divine hypostases and thus, by implication, of the divinity of the Holy Spirit as well. For these theologians, the consensus

8.According to Müller (1952:629), the word theopoiessis [deification] occurs only three times in Athanasius' works, namely in his Orationes contra Arianos 1, 2 and 3. Elsewhere, Athanasius uses the verb theopoieisthai, emphasising the continuous working of the Spirit in Christian believers. Van Haarlem (1961:135-143) remarks: 'De inhoud van de aan de Griekse wereld ontleende terminologie der vergoddelijking is in de orationes volkomen bijbels. Het begrip vergoddelijking grenst aan dat van de aanneming tot kinderen. Athanasius gebruikt het woord theopoièsis in dezelfde zin waarin Paulus spreekt van de huiothesia (cf. Rom. 8:15 en 23; 9:4; Gal. 4:5 en Efez. 1:5). (...) De vergoddelijking wil niets anders zeggen dan dit, dat wij door de Geest in gemeenschap komen met God, door het geloof, dat wij kinderen worden van de Vader, dat wij in genade worden aangenomen.'

9. An edition of the letters is in MPG 26. A French translation by Jean Lebon can be found in SC 15 and an English translation in Shapland (1951). For these highly important letters, see also Roldanus (1968/1977, 389-391)

10.This term translates as 'of one substance (with the Father)'. The term was originally employed to indicate the divinity of the Son. 
that the Spirit was homoousios was orthodox. Thus, the term applied in Nicea to the Son was also applied to the Holy Spirit. Three fathers from Cappadocia, once a province in Asia Minor and now a region in central Turkey, were members of this party. These fathers were Basilius the Great, bishop of Caesarea, his brother, Gregory, bishop of Nyssa (a highly original thinker and mystic), and their mutual friend, the famous preacher, Gregory of Nazianzus, who was later given the title of 'The Theologian'.

We need not expand on how these thinkers, well versed in philosophy and especially in Neo-Platonism, found a common basis resulting in the formula mia ousia, treis hypostaseis [one being, three substances] (Loofs 1968:196-205; Adam 1970:I, 234ff.; Kelly 1968:258-269; Dünzl 2007; Lössl 2010:178-188 ${ }^{11}$. It should not be denied that this doctrine of the Trinity (a non-biblical term!) was completed with the help of Greek philosophy. Unlike ever before, the intellectual achievements of Greek philosophers were used in and by the Church. However, we would also be misguided if we simply followed Adolf von Harnack in his famed statement that the Christian dogma (and in particular the trinitarian dogma) was 'a work of the Greek spirit on the soil of the Gospel' (Von Harnack 1909/1965:20; cf. Sietsma 1933; Slotemaker de Bruine 1933). The purpose of the Cappadocians was not to subordinate faith to philosophy, but to define the reality of faith in a scientific manner, especially the doctrine of the divinity of the Holy Spirit. In other words, they did not force Neo-platonic notions onto the Christian faith, but tried to employ philosophical categories in their description of it. One may compare this procedure with the theological method of their great contemporary in the West, the African theologian Augustine (354-430). According to Augustine, Christian (trinitarian) faith is not established by philosophical reasoning. Rather, the objective statements of faith reveal the principles and premises contained therein (Augustine, De Trinitate 15, 6; CCL 50A, 472).

\section{Basilius the Great}

With regard to our current topic, credit should be given to Basilius for developing the theological concepts. More lucid than previously, as a result of philosophical reflection, the concepts of ousia [being, essence] and hypostasis [actualisation, mode of being] were differentiated. From reflection on the content of the biblical revelation he concluded that all three divine hypostases have the following in common: immeasurability, incomprehensibility, 'uncreated-ness' and 'un-space-ness'. They are one unity of being, but each has special characteristics. Typical of the first hypostasis is

11.In the Western tradition, following Tertullian, this was soon 'translated' as: und substantia, tres personae [one substance, three persons]. It should be noted that the word 'persons' is construed in a particular way. It does not mean 'persons' in the modern sense as indicating individuals with their own will, consciousness etcetera. This was rightly seen by John Calvin, amongst others. Calvin made the sharp statement: 'Les anciens Docteurs ont usé de ce mot de Personnes: et ont dit que en Dieu il y a trois personnes: non point comme nous parlons en notre langage commun, appellant trois hommes, trois persones (...) Mais ce mot de Personnes en ceste matiere est pour exprimer les proprietez, lesquelles sont en l'essence en ceste, (cf. Krusche 1957:1ff.; the quote is on p. 4). For mos sont en l'essence de Dieu' (cf. Krusche 1957:1f., the quote is on p. 4). For more on the concepts of substantia, persona, ousia, hypostasis, prosôpon, see Adam (1970:233-40) Kelly (1976:114-115, 242ff.) and Berkhof (1965:123). One may be reminded of Augustine's famous words: 'Dictum est tamen tres personae non ut illud diceretur sed ne taceretur' (De trinitate 5,$10 ;$; CC 50,217 ), that is 'So we say three persons,
not in order to say that precisely, but in order not to be reduced to silence' (Hill not in order to s his 'uncreatedness' and Fatherhood; typical of the second hypostasis is his Sonship and the fact that he is the only begotten; typical of the third hypostasis is its sanctifying power and the fact that he proceeded from the Father. Common to all hypostases is their 'personhood'. This also applies to the Holy Spirit. The Spirit deserves equal honour (homotimos) and glory (homodoxos), according to Basilius.

Regardless of all the aforementioned information, Basilius does not use the word homoousios [of the same substance] in reference to the Holy Spirit. Why not? Athanasius did use it explicitly. Hermann Dörries (1956:181, 1966:118-44) explains this silence by noting Basilius's differentiation between dogma and kerygma (cf. also Luislampe 1981). According to Basilius, dogma is something different from kerygma. Whereas the former is kept silent, the content of the latter should be proclaimed (De Spiritu Sancto 27, 65 ff.; SC 17, 232ff.; cf. De Boer 1969-70, 363-372). What we know of the three hypostases is kerygma, whereas their unity is dogma. However, it is doubtful that this is the only reason for Basilius's silence. Sible de Boer (1969-70:362-380) proposed that Basilius's neo-platonic background would have prevented him from using the term homoousios. Benoit Prusche, in his edition of Basilius's De Spiritu Sancto, is of the opinion that the prudent Basilius shunned the word homoousios because it was a charged term in the aftermath of the preceding Christological discussion (SC 17; cf. Kelly 1967:342-343).

Whatever the reason might have been, the divinity of the Holy Spirit is the very implication of Basilius's doctrine, regardless of whether or not he overtly expresses it with the term homoousios. His friend, Gregory of Nazianzus, whose theology was deeply driven by a personal longing for salvation, explicitly states: the Spirit is homoousios, and thus God (Epistula 58; MPG 37, 116).

\section{Constantinople 381 and the confession of the Holy Spirit}

It was the theology of the Cappadocian fathers that united all parties at the council of Constantinople (Ritter 1965). New creedal formulas about the Holy Spirit were added to the original Creed of Nicea (325): ${ }^{12}$

And (we believe) in the Holy Spirit, the Lord and Giver of life, who proceeds from the Father,

who with the Father and the Son together is worshipped and glorified,

who has spoken through the prophets.

(The Creed of Nicea 325)

In this way, the Christian belief in the Holy Spirit is confessed in the only fully-ecumenical confession of faith, in

12.For the differences between the two symbols, see Kelly (1976:301-305). What is confessed of the Holy Spirit is new. It should be noted that, in the original Greek wording, 'being Lord' is expressed by an adjective (to kyrion) and not a substantive (ton kyrion). Kelly is mistaken in writing ton kyrion. From this cautious wording (based on the reticence of Basilius and his advocate at the council, Gregory of (based on the reticence of Basilius and his advocate at the council, Gregory of Nyssa) the following can be adduced: the Spirit is ruling and governing, yet does not carry the Christ-title 'Lord. Was all this not enough for Gregory of Nazianzus, who during the 381 council was consecrated bishop of Constantinople, and migh the one of the reasons why he resigned the episcopal see before the end of the ear? At a next council (382), the Nicene term homoousios was applied to the Spirit as well. It should further be noted that the Western churches confessed ton kyrion whilst translating the passage as: Et in spiritum sanctum, dominum et vivificantem ... (cf. Lietzmann 1914:37, 39). 
other words, the only creed accepted by all main churches across the world. This creed is the result of a long doctrinal process. When this creed (officially called the NicenoConstantinopolitanum, or the Creed of Nicea as it was endorsed and supplemented at the council of Constantinople in 381) speaks of the Spirit as being Lord and Giver of life, it reflects the theological conviction of Athanasius. In the assertion about worship and glorification, we hear an echo of the pneumatology of Basilius (Athanasius Ad Serap. 1, 31; Basilius, Ep. 90, 2; cf. Kelly 1967:342).

One further observation can be made in this context. The words synproskynoumenon [worshipped together with] and syndoxadzomenon [florified together with], testify that thanksgivings, prayers and blessings are also directed at the Holy Spirit. Hendrik Berkhof, in his famous and very influential Christelijk geloof (first edition 1973:349), opined that the believer does not pray to the Holy Spirit. In the seventh edition (2007:328), however, he changed his mind, stating that when Christians address the Holy Spirit in their prayers, this is done in the context of their belief in 'the one God in his activity towards us'. The worldwide received confession of faith teaches the same thing. Moreover, such an understanding was and still is the explicit practice of Christian churches both in the eastern and western regions of the world. ${ }^{13}$

\section{The confession of the Holy Spirit}

In the preceding paragraphs, I sketched the doctrinal development up to and including the famous council of Constantinople. Such a short overview of dogmas and formulas might result in a one-sided impression. We run the risk of thinking that the Church's dogma is simply some abstract teaching invented by the ingenuity of individuals.

I would rather argue for the opposite. True dogmatic reflection is aimed at expressing the mystery of God in the realm of human thinking, but without trying to unveil divine truth in a rationalistic manner. The dogma of the Trinity, and with it the dogma of the Holy Spirit, is an interpretation of who God is, expressed in rational words. It is not; however, a case of logical reasoning, but of confession. We now turn to this second and most important aspect of our subject. How did the oldest formulas, spoken at baptism, develop into the structured trinitarian confessions of faith that have been passed down to us? And what do they say about the Holy Spirit?

\section{From creedal formulas to symbols}

John Norman Davidson Kelly in particular, in his famous book Early Christian Creeds, ${ }^{14}$ demonstrated how age-old

13.There are many examples of prayers, not only about, but also to the Holy Spirit. They occurred not only in the Early Church (cf. Basilius in SC 17, 247f.; Origenes's Hom. in Lv 1, 1; cf. ed. Baehrens in GCS 6, 1920:281), but also in later ages. The borderline between prayers, acclamations, hymns and doxologies tends to be fluid and vague. There are many examples of prayers to the Holy Spirit. See, for instance the liturgical prayers in Jungmann (1952). There are hymn books across the world that contain hymns to and about the Holy Spirit. André Wilmart gives an extensive (and even extreme) example from the medieval mystical tradition: Oraciones (and even extreme) example from the medieval mystical tradition: Oraciones ad spiritum sanctum secundum septem dona ipsius [Prayers to the Holy Spirit according to its seven gifts] (Wilmart 1932:466-473). It seems best to underline that, according to well-balanced Christian doctrine, all prayers directed at the
Holy Spirit are also still directed at the one and triune God. For critical remarks on Berkhof's original view, see Schoonenberg $(1974: 129,133)$.

14.For the relation between baptism and confession, see also Ferguson (2009). summaries of faith developed into well-known creeds, like the so-called Apostle's Creed or Apostolicum and the Niceno-Constantinopolitanum. In the beginning of his book, Kelly incorporates important research results from, amongst others, Alfred Seeberg (1903) and Charles Harald Dodd (1936).

Seeberg argues in his 1903 study on the catechism of primitive Christianity (Der Katechismus der Urchristenheit) that, from the Church's earliest times onwards, many fixed formulas existed. In Romans 6:17, for example, Paul uses the expression 'form of teaching' (typos didachès). Also, in I Corinthians 15:3, he speaks of the faith he had received from predecessors in the apostolic tradition; a faith which was passed down in a fixed formula. Other summaries, used for catechetical purposes, are Romans 1:3ff., Romans 8:34, I Peter 3:18ff. and I Timothy 3:16. Seeberg convincingly points out several fixed statements of faith ('Glaubenformeln') already present in the writings of the New Testament. His conclusion is that the ancient Christian creeds, both in the Greek East and the Latin West, were structured in three parts according to the trinitarian confession taught during early Christian catechesis: 'Das altkirchliche Symbol in seinen morgen- und abendländischen Gestalten bezeichnet die nach dem trinitarischen Schema geordnete Aufzählung von Katechismuswahrheiten' (Seeberg 1903:273).

To Seeberg, a pioneer of the so-called Formgeschichte (Form Criticism) in New Testament studies, it became clear that semi-formal confessions already existed in the earliest Christian congregations, occurring at baptisms, during worship, and in homilies and catechetical lessons. Texts like I Corinthians 12:3 and Romans 10:9 mention one of the oldest confessions: Kyrios Ièsous. Apart from this declaration of faith, there are many other confessions that Jesus is the Christ and the Son of God.

The oldest formulas are not only about Jesus Christ, but also about God the Father, as can be seen in I Corinthians 8:6, I Timothy 2:5ff. and 6:13 ff., to name but a few examples. Relatively clear 'trinitarian' formulas are also present, like, for example, II Corinthians 13:13, Matthew 28:19, I Corinthians 12:4ff., II Corinthians 1:21ff. and I Peter 1:2 (Kelly 1967:22-23). From all these witnesses it is clear that, even from the very beginning, the perception of a triadic manifestation of God was anchored deep within the Christian faith. ${ }^{15}$ Although explicitly trinitarian confessions are sparse $^{16}$ the initial pattern is noticeably present.

15. As it was already in some Jewish circles (cf. e.g. Kretschmar 1956; Adam 1970:117f.)

16.WE dare to speak of 'trinitarian' (and not only 'triadic') structured confessional formulas. Although the formulations in, for example, Ephesians 4:4ff., Jude 20 f., II Thessalonians 2:13ff. are not fixed and still pluriform, a primitive trinitarian pattern is clear. Moreover, in these early testimonies, the Spirit is spoken of in a 'personal' way: The Spirit 'helps us in our weakness' and 'intercedes for us' (Rom $8: 26$ ), 'searches all things' (I Cor 2:10), 'will convict the world of guilt in regard to sin and righteousness and judgment' (Jn 16:8), etcetera. Often it is not easy to sin and righteousness and judgment' (Jn 16:8), etcetera. 'Often it is not easy to assess the exact nature and applicability of terms such as 'triadic' and '(primitive) trinitarian'. For more in this regard, see, for example, the balanced view of Selwyn 1977:247-250: 'The Trinitarian formula in [1 Peter] i. 2'). Of crucial importance to (1956), Quis (1956), Quispel (1964/2008) and Veenhof (1974) point to the great importance of the testimony of Jewish Christians (or Christian Jews) to the concept of the Spirit as a 'person', even in texts preceding the Pauline and Johannine writings. 
The most peculiar element of the Christian faith was emphasised from the earliest times, namely lèsous Kyrios. But stress was also laid on the confession of both the Father and the Holy Spirit. By confessing the charismatic works of the Holy Spirit, believers professed their awareness of living in the Messianic era, the age of the New Covenant (Van Unnik 1964:63-75).

The practice of baptism played an important role in the process leading up to fixed confessions. The commission to baptize in Matthew 28:19 especially provided the various creeds with a common trinitarian structure. ${ }^{17} \mathrm{~A}$ basic and essential element of the baptismal rite was always the threefold immersion, preceded by three sequential questions ('Do you believe in God the Father ... in Jesus Christ his Son ... and in the Holy Spirit...?') and three answers ('Pisteuō/ Credo [I believe]'). The three slightly different baptismal questions and answers increasingly expanded and, in so doing, gave birth to various Creeds or Symbols. Since $c$. 250 , the traditio and redditio symboli, the 'transmission' and 'rendition' of the creed, function as final acts of an extensive catechetical instruction.

\section{Clemens, Justin, Irenaeus}

Not only in the writings which would become part of the New Testament, but also in Christian texts of the same era, such as the so-called 'Apostolic Fathers', we find 'triadic' and even primitive 'trinitarian' proclamations. These statements speak of the Holy Spirit as well.

In I Clement $(46,6)$, the letter written by Clement of Rome to the Christians at Corinth in the year 96, it is asked: 'Or do we not have one God and one Christ and one Spirit of grace that was poured out upon us?' (cf. Holmes 2007:106107). Contesting the disagreement amongst the Corinthians, Clement emphasises unity, and in the process probably refers to the trinitarian formula of the baptism. Later on, the letter speaks in trinitarian terms again: 'For as surely as God lives, and as the Lord Jesus Christ lives, and the Holy Spirit ...' (I Clemens 58, 2; cf. Holmes 2007:122-123). The Christian elect believe in the triune God, a fact which, if seen in conjunction with some sort of oath formula, reminds of baptism (thus Joseph Barber Lightfoot as referred to in Kelly 1967:67; cf. e.g. Opitz 1960:50).

Another source of trinitarian formulas and thus also of statements about the Spirit is Justin Martyr. In his First Apologia, written in Rome in c. 155, he writes:

They [the baptised] receive then a bath in water in the name of God the Father and Lord of the universe, and of our Saviour Jesus Christ, and of the Holy Spirit.

(Apologia I, 61, 3; Krüger 1968:51-52; cf. Marcovich 1994:118)

17.I mention only Ephraem Syrus (Adam 1970:253) as a typical example of the Syrian church, Basilius (Dörries 1966:132-134) as a good example of the Greek church, and Tertullian (Bender 1961) as typical of the Western church. Even in Augustine, the commission to baptize is the essential base to his trinitarian doctrine: 'Domine deus noster, credimus in te patrem et filium et spiritum sanctum. Neque enim diceret veritas: Ite, baptizate omnes gentes in nomine patris et filii et spiritus ancti nisi trinitas esses' (De trinitate 15, 28; CCL 50A, 533), in translation (cf. Hill 1991/2007:436, but here essentially modified): 'O Lord our God, we believe in you, Father, Son and Holy Spirit. Truth would not have said, Go and baptize all the
nations in the name of the Father and of the Son and of the Holy Spirit (Matt 28:19), nations in the name of the
unless you were a trinity'.
With regard to the Lord's Supper, he writes:

Thereupon bread and a cup of wine mixed with water is brought to the president of the brethren. He takes them and gives praise and glory to the Father of the universe, through the name of the Son and of the Holy Spirit ...

(Apologia I, 65, 3; Krüger 1968:56; cf. Marcovich 1994:129)

Also important in this context is Irenaeus. In a famous passage, this student of Polycarp (who himself, according to Irenaeus, kept company with John in Asia Minor), states that the substance of the tradition (hè dynamis tès paradosis) is generally the same:

The Church ... has received from the apostles and their teachings this faith: [the belief] in one God, the Father Almighty, who created heaven and earth and the sea and all things that are in it; and in one Christ Jesus, the Son of God, who became flesh for the sake of our salvation; and in the Holy Spirit ...

(Adv. Haer. 1, 10, 1; SC 264, 154)

The canon of truth, ${ }^{18}$ in later tradition generally known as the rule of faith (regula fidei) ${ }^{19}$ is not tied up in a fixed formula, but the content of it is. In his Demonstration of the Apostolic Preaching, Irenaeus, probably the most important theologian of the second century, says:

This then is the order of the rule of our faith, and the foundation of the building, and the stability of our conversation: God, the Father, not made, not material, invisible; one God, the creator of all things: this is the first article of our faith. The second article is: The Word of God, Son of God, Christ Jesus our Lord, who was manifested to the prophets according to the form of their prophesying and according to the method of the dispensation of the Father: through whom all things were made; who also at the end of the times, to complete and gather up all things, was made man among men, visible and tangible, in order to abolish death and show forth life and produce a community of union between God and man. And the third article is: The Holy Spirit, through whom the prophets prophesied, and the fathers learned the things of God, and the righteous were led forth into the way of righteousness; and who in the end of the times was poured out in a new way upon mankind in all the earth, renewing man unto God.

(Demonstratio 6; SC 62, 39-40; I here follow Armitage Robinson's 1920 translation of the Armenian text)

The same tradition exerts itself here as in the writings of Tertullian, Hippolytus, Cyprian and Origen, to name only four examples (Kelly 1967:82-94; Jaschke 1976:2535). Notwithstanding underlying variations, there is full agreement on the trinitarian structure in this tradition summarised in the 'rule of faith'. The confession of the Father, Son and Holy Spirit is the unifying element. In this confession, statements about the Spirit are constantly present and closely connected to the confession of the Father and the Son.

\section{The Holy Spirit according to the Symbolum Romanum}

The baptismal questions-and-answers formula developed into symbols. The early baptismal confession of the church

18.The expression kanön tès alètheias in Irenaeus, for example, Adv. Haer. 1, 9, 4.

19.For these concepts, see the (still leading) study of Van den Eynde (1933:281-313, esp. 282-289 on the importance of Irenaeus). Cf. also Kelly (1967:76-88) and the entry 'Rule of Faith' in ODCC 2005. 
in Rome is the most well-known example of a confession of faith receiving a fixed form. This must have happened either at the end of the second century (Kelly 1967:113; 127-130), or at the beginning of the third (Vokes 1978/1993:535; cf. Westra 2000:Chapter I, passim). The symbol confesses in the third article:

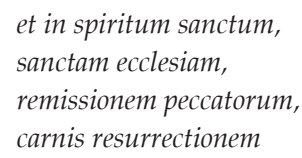

(Lietzmann 1914:10) ${ }^{20}$

Note that this confession - its subsequent, extended form became well known as the so-called Apostle's Creed, or Symbolum apostolorum - speaks extensively of the Holy Spirit. Indeed, its whole third part deals with the Holy Spirit. The church is confessed to be the creation of the Spirit, holy because of the Spirit's inhabitation. Also, the forgiveness of sins, which happens first and foremost at baptism, and the resurrection of the flesh are gifts from the Spirit.

This baptismal confession is an expression of the faith and hope of the early Christian church. It is a compendium of popular theology (Kelly 1967:131, 165); there was no council to define its text. The text received its trinitarian structure from the very beginning, first of all employing the trinitarian design available in the formulas used at baptisms, but also in accordance with the trinitarian elements in early Christian hymns and prayers. Therefore, in addition to the Son and the Father, it emphatically speaks of the Holy Spirit as well.

As a matter of fact, there is no evidence of an elaborated trinitarian theology, the likes of which are to be found, for instance, with the church fathers of the fourth century. It cannot be denied, however, that these early testimonies also see the Spirit as a divine 'Person', who is closely associated with the Father and the Son; and not simply as a gift or power. Already at the end of the first century, the divine status of the Spirit is affirmed by Clement of Rome in his letter to Corinth. Justin Martyr, in his Apology, says that the Christians worship and adore the prophetic Spirit: '...pneuma te to prophètikon sebometha kai proskunoumen ...' (Apologia I, 6, 2; Krüger 1968:4-5; cf. Marcovich 1994:40). For Irenaeus, the Spirit is the wisdom of God, who, together with the Son, was present with God even before the world's creation. The Spirit, moreover, is affirmed by Irenaeus as one of the two hands with which God once created and still recreates mankind. From the very beginning, the Church's liturgical formulas and doxologies mention the Spirit together with the Father and the Son.

\section{Acknowledgements Competing interests}

The author declares that he has no financial or personal relationship(s) which may have inappropriately influenced him in writing this article.

20.There is also a Greek version. The oldest text was probably Greek. In translation 'And [I believe] in the Holy Spirit, the holy church, the foregiveness of sins, the resurrection of the body.'

\section{References}

Adam, A., 1970, Lehrbuch der Dogmengeschichte: I. Die Zeit der Alten Kirche, Gütersloher Verlagshaus Mohn, Gütersloh.

Augustinus, 1969, Sancti Avrelii Avgustini Enchiridion ad Lavrentium de fide et spe et caritate, cvra et stvdio E. Evans, pp. 21-114, CCL 46, Brepols, Turnhout.

Augustinus, 1968, Sancti Avrelii Avgustini De Trinitate. Libri I-XII; XIII-XV, cvra et stvdio W.J. Mountain et F. Glorie, CCL $50+50 \mathrm{~A}$, Brepols, Turnhout.

Barbel, J., 1958, 'Zur “Engel-Trinitäts-Lehre" im Urchristentum', Theologische Revue 54, 49-58.

Barbel, J., 1961, Christos Angelos: Die Anschauung von Christus als Bote und Engel in der gelehrten und volkstümlichen Literatur des christlichen Altertums. Zugleich ein Beitrag zur Geschichte des Ursprungs und der Fortdauer des Arianismus, Hanstein, Bonn.

Basilius, 1947, De Spiritu sancto: Basile de Césarée, Traité du Saint-Esprit. Texte grec, introduction, traduction et notes de Benoit Pruche (SC 17), Éditions du Cerf, Paris. Bender, W., 1961, Die Lehre über den Heiligen Geist bei Tertullian, Hüber, München.

Berkhof, H., 1965, De leer van de Heilige Geest, Callenbach, Nijkerk.

Berkhof, H., 1973, Christelijk geloof: Een inleiding tot de geloofsleer, Callenbach, Nijkerk.

Berkhof, H., 2007, Christelijk Geloof, Kok, Kampen.

Briggman, A., 2009, 'Measuring Justin's Approach to the Spirit: Trinitarian Conviction and Binitarian Orientation', Vigiliae Christianae 63, 107-137.

Briggman, A., 2010, 'Re-evaluating Angelomorphism in Irenaeus: The Case of Proof of the Apostolic Preaching 10', Journal of Theological Studies 61, 583-595.

Bucur, B.G., 2007, 'Revisiting Christian Oeyen: "The Other Clement" on Father, Son, and the Angelomorphic Spirit', Vigiliae Christianae 61, 381-413.

Bucur, B.G., 2009, Angelomorphic Pneumatology: Clement of Alexandria and Other Early Christian Witnesses, Brill, Leiden \& Boston.

Crouzel, H., 1976, Geist (Heiliger Geist): Väterzeit. Reallexicon für Antike und Christentum, Band IX, 510-545.

Daniélou, J., 1957, 'Trinité et Angélologie dans la théologie judéo-chrétienne', Recherches de science religieuse 45, 5-41

Daniélou, J., 1958, Théologie du Judéo-Christianisme, Desclée De Brouwer, Tournai.

De Boer, S., 1963-1964, 'Basilius de Grote en de homoousie van de Heilige Geest', Nederlands Theologisch Tijdschrift 18, 362-380.

De Boer, S., 1969-1970, 'Paradosis, dogma en kerugma naar de opvatting van Basilius de Grote', Nederlands Theologisch Tijdschrift 24, 363-372.

Dodd, C.H., 1936/1980, The Apostolic Preaching and Its Developments, Baker Book House, Grand Rapids, MI. (Repr. 1936, Hodder \& Stoughton, London.)

Dörries, H., 1956, De Spiritu Sancto: Der Beitrag des Basilius zum Abschluss des trinitarischen Dogmas, Vandenhoeck und Ruprecht, Göttingen.

Dörries, H., 1966, 'Basilius und das Dogma vom Heiligen Geist', in H. Dörries (Hrsg.), Wort und Stunde: I. Gesammelte Studien zur Kirchengeschichte des vierten Jahrhunderts, pp. 118-144, Vandenhoeck und Ruprecht, Göttingen.

Dünzl, F., 2007, A Brief History of the Doctrine of the Trinity in the Early Church, Continuum, London \& New York.

Ferguson, E., 2009, Baptism in the Early Church: History, Theology and Liturgy in the First Five Centuries, Eerdmans, Grand Rapids, MI \& Cambridge.

Fossum, J.E., 1985, The Name of God and the Angel of the Lord: Samaritan and Jewish Concepts of Intermediation and the Origin of Gnosticism, Mohr, Tübingen.

Gross, K., 1969, 'Finger', Reallexikon für Antike und Christentum VII, 909-946.

Hill, E., 1991/2007, The Works of Saint Augustine: A Translation for the $21^{\text {st }}$ Century: The Trinity (De Trinitate), introduction, translation and notes by Edmund Hill, Hydepark, New City Pess, New York.

Holmes, W., 2007, The Apostolic Fathers: Greek Texts and English Translations, 3rd edn., ed. \& transl. Michael W. Holmes, after the earlier work of J.B. Lightfoot and J.R. Harmer, Baker Academic, Grand Rapids, MI.

Irenaeus, 1920, St Irenaeus, The Demonstration of the Apostolic Preaching, translated from the Armenian with Introduction and Notes by Armitage Robinson, SPCK \& from the Armenian with Introduct
MacMillan, London \& New York.

Irenaeus, 1952, Against Heresies: Irénée de Lyon, Contre les hérésies, Livre III, Texte Latin, fragments Grecs, Introduction, traduction et notes de F. Sagnard (SC 34), Éditions du Cerf, Paris.

Irenaeus, 1956, Against Heresies: Irénée de Lyon, Contre les hérésies, Livre IV, Édition critique sous la direction de Adelin Rousseau, Tome I + II (SC 100), Éditions du Cerf, Paris.

Irenaeus, 1969, Against Heresies: Irénée de Lyon, Contre les hérésies, Livre V, Édition critique par Adelin Rousseau, Louis Doutreleau, Charles Mercier, Tome I + II (SC 152-153), Éditions du Cerf, Paris.

Irenaeus, 1974, Against Heresies: Irénée de Lyon, Contre les hérésies, Livre III, Édition critique par Adelin Rousseau et Louis Doutreleau, Tome I + II (SC 210-211) Éditions du Cerf, Paris.

Irenaeus, 1979, Against Heresies: Irénée de Lyon, Contre les hérésies, Livre I, Édition critique par Adelin Rousseau et Louis Doutreleau, Tome I + II (SC 263-264), Éditions du Cerf, Paris.

Irenaeus, 1982, Against Heresies: Irénée de Lyon, Contre les hérésies, Livre II, Édition critique par Adelin Rousseau et Louis Doutreleau, Tome I + II (SC 293-294), critique par Adelin Rous
Éditions du Cerf, Paris. 
Irenaeus, 1995, Irénée de Lyon, Démonstration de la prédication apostolique, Introduction, traduction et notes par Adelin Rousseau (SC 406), Éditions du Cerf, Paris.

Jaschke, H.J., 1976, Der Heilige Geist im Bekenntnis der Kirche: Eine Studie zur Pneumatologie des Irenäus von Lyon im Ausgang vom altchristlichen Glaubensbekenntnis, Aschendorff, Münster.

Jungmann, J.A., 1952, Missarum sollemnia: Eine genetische Erklärung der römischen Messe, Dritte Auflage, Herder, Wien.

Kelly, J.N.D., 1967, Early Christian Creeds, Adam \& Charles Black, London.

Kelly, J.N.D., 1968, Early Christian Doctrines, Adam \& Charles Black, London.

Kettler, F.H., 1962, 'Trinität, Dogmengeschichlich', in Die Religion in Geschichte und Gegenwart, pp. 1025-1032, Dritte Auflage, Band VI, Mohr Siebeck, Tübingen.

Kretschmar, G., 1956, Studien zur frühchristlichen Trinitätstheologie, Mohr, Tübingen. Krüger, G., 1968, Die Apologien Justins des Märtyrers, Minerva, Frankfurt.

Krusche, W., 1957, Das Wirken des Heiligen Geistes nach Calvin, VandenHoeck und Ruprecht, Göttingen.

Lebreton, J., 1927-1928, Histoire du dogme de la Trinité des origines au concile de Nicée. 1. Les origines. 2. De s. Clément à s. Irénée, Beauchesne, Paris.

Lietzmann, H., 1914, Symbole der alten Kirche, A. Markus \& E. Weber's Verlag, Bonn.

Loofs, F., 1968, Leitfaden zum Studium der Dogmengeschichte, 1. und 2. Herausgeben von Kurt Aland, 7., ergänzte Auflage, Max Niemeyer Verlag, Tübingen.

Lössl, J., 2010, The Early Church: History and Memory, T\&T Clark International, London \& New York.

Luislampe, P., 1981, Spiritus vivificans: Grundzüge einer Theologie des Heiligen Geistes nach Basilius von Caesarea, Aschendorff, Münster.

Mambrino, J., 1957, 'Les deux mains de Dieu dans l'oeuvre de saint Irénée', Nouvelle Revue Théologique 79, 355-370.

Marcovich, M., 1994, Iustini Martyris Apologiae pro Christianis, ed. Miroslav Marcovich, Walter de Gruyter, Berlin.

Minns, D., 2010, Irenaeus: An Introduction, T\&T Clark International, London \& New York.

Müller, G., 1952, Lexicon Athanasium, Walter de Gruyter, Berlin.

Oberdorfer, 2005, 'Trinität/Trinitätslehre: Dogmengeschichtlich: Alte Kirche', in Die Religion in Geschichte und Gegenwart, pp. 602-607, Vierte Auflage, Mohr Siebeck, Tübingen.

ODCC, 2005, The Oxford Dictionary of the Christian Church, ed. F.L. Cross, 3rd edn. ed. E.A. Livingstone, Oxford University Press, Oxford.

Opitz, H., 1960, Ursprünge frühkatholischer Pneumatologie: Ein Beitrag zur Entstehung der Lehre vom Heiligen Geist in der römischen Gemeinde unter Zugrundelegung des I. Clemens-Briefes und des 'Hirten' des Hermas, Evangelische Verlagsanstalt, Berlin.

Quispel, G., 1964, 'De Heilige Geest volgens de Oude Kerk', in De Spiritu Sancto: Bijdragen tot de leer van de Heilige Geest bij gelegenheid van het $2^{e}$ eeuwfeest van het Stipendium Bernardinum, pp. 77-88, Kemink, Utrecht.
Quispel, G., 2008, 'The Holy Spirit According to the Early Church', in J. van Oort (ed.) Gnostica, Judaica, Catholica: Collected Essays of Gilles Quispel, pp. 739-748, Brill Academic Publishers, Leiden \& Boston.

Raddle-Gallwitz, A., 2011, 'The Holy Spirit as Agent, not Activity: Origen's Argument with Modalism and its Afterlife in Didymus, Eunomius, and Gregory of Nazianzus', Vigiliae Christianae 65, 227-248.

Ritter, A.M., 1965, Das Konzil von Konstantinopel und sein Symbol, Vandenhoeck und Ruprecht, Göttingen.

Roldanus, J., 1968/1977, Le Christ et l'homme dans la théologie d'Athanase d'Alexandrie, Brill, Leiden

Schmidt, M.A., 1958, 'Heiliger Geist, dogmengeschichtlich', in Die Religion in Geschichte und Gegenwart, pp. 1279-1280, Dritte Auflage, Band II, Mohr Siebeck, Tübingen

Schoonenberg, P., 1974, 'Berkhof en het Credo', in Weerwoord, pp. 127-135, reacties op Dr H. Berkhof's 'Christelijk geloof', Callenbach, Nijkerk.

Seeberg, A., 1903/1966, Der Katechismus der Urchristenheit, Kaiser Verlag, München (Repr. 1903, Leipzig.)

Selwyn, E.G., 1977, The First Epistle of St. Peter, Macmillan, London.

Sietsma, K., 1933, Adolf von Harnack: Voornamelijk als dogmahistoricus, Meinema, Delft.

Shapland, C.R.B., 1951, The letters of Saint Athanasius concerning the Holy Spirit, Epworth Press, London \& New York.

Slotemaker de Bruine, M.C., 1933, Adolf von Harnack's kritische Dogmengeschichte, Nijhoff, 's-Gravenhage.

Van den Eynde, D., 1933, Les normes de l'enseignement chrétien dans la littérature patristique des trois premiers siècles, J. Duculot/Gabalda \& Fils, Gembloux/Paris.

Van Haarlem, A., 1961, Incarnatie en verlossing bij Athanasius, Veenman, Wageningen.

Van Unnik, W.C., 1964, 'De Heilige Geest in het Nieuwe Testament', in De Spiritu Sancto: Bijdragen tot de leer van de Heilige Geest bij gelegenheid van het $2^{e}$ eeuwfeest van het Stipendium Bernardinum, pp. 63-75, Kemink, Utrecht.

Veenhof, J., 1974, De Parakleet: Enige beschouwingen over de parakleet-belofte in het evangelie van Johannes en har theologische betekenis, Kok, Kampen.

Vokes, F.E., 1978/1993, 'Apostolisches Glaubenskenntnis', in Theologische Realenzyklopedie, pp. 528-554, Band III, Walter de Gruyter, Berlin.

Von Harnack, A., 1965, Lehrbuch der Dogmengeschichte, Band I, Wissenschaftliche Buchgesellschaft, Darmstadt. (Repr. 1909, of 4th edn. Tübingen.)

Westra, L., 2000, The Apostle's Creed: Origin, History, and some early Commentaries, Brepols, Turnhout.

Wilmart, A., 1971, Auteurs spirituels et textes dévots du Moyen Age latin, Études Augustiniennes, Paris.

Zandee, J., 1981, 'The Teachings of Silvanus and Jewish Christianity', in R. van den Broek \& M.J. Vermaseren (eds.), Studies in Gnosticism and Hellenistic Religions, presented to Gilles Quispel, pp. 498-584, Brill, Leiden. 